\title{
Modeling the role of songbirds and rodents in the ecology of Lyme disease
}

\author{
Antonia R. Giardina, Kenneth A. Schmidt, Eric M. Schauber, \\ and Richard S. Ostfeld
}

\begin{abstract}
Small rodents such as the white-footed mouse (Peromyscus leucopus) and the eastern chipmunk (Tamias striatus) efficiently transmit Borrelia burgdorferi, the etiologic agent of Lyme disease, to feeding ticks, whereas other hosts of ticks are less efficient reservoirs of B. burgdorferi. We examined the roles of ground-foraging and groundnesting songbirds as alternative hosts for ticks, focusing on their potential to dilute the infection prevalence of ticks (Ixodes scapularis, the black-legged tick) with B. burgdorferi. We developed a mathematical model based on the relative use by ticks of rodent and bird hosts across varying host densities. We parameterized the model for sites in southeastern New York State using original data and for the northeastern United States using published values. Our results indicate that American robins (Turdus migratorius), ovenbirds (Seiurus aurocapillus), veeries (Catharus fuscescens), and wood thrushes (Hylocichla mustelina) have a low capacity to dilute the prevalence of tick infection, particularly when rodents are at moderate to high densities. We attribute this result to low use by ticks of birds and a low density of birds relative to that of rodents. Only when rodents constitute less than ca. 10-20\% of the combined rodent and songbird host community are birds capable of substantially reducing the infection prevalence of ticks. In years or habitat types in which the density of rodents is low but that of ground-dwelling songbirds is high, the risk of human exposure to Lyme disease may reduced because birds dilute the infection prevalence of tick vectors.
\end{abstract}

Résumé : Les petits rongeurs tels la Souris à pattes blanches (Peromyscus leucopus) et le Tamia rayé (Tamias striatus) assurent efficacement la transmission de Borrelia burgdorferi, l'agent étiologique de la maladie de Lyme, aux tiques hématophages, alors que d'autres hôtes des tiques sont des réservoirs moins efficaces de $B$. burgdorferi. Nous avons examiné le rôle des oiseaux passereaux qui s'alimentent et nichent au sol comme hôtes de rechange pour les tiques, portant une attention particulière à leur capacité de diluer la prévalence des borrélioses transmises par Ixodes scapularis. Nous avons conçu un modèle mathématique basé sur l'utilisation relative que les tiques font des rongeurs et des oiseaux comme hôtes à différentes densités d'hôtes. Nous avons déterminé les paramètres du modèle pour des endroits situés dans le sud-est de l'état de New-York à partir de données originales et à partir de données publiées pour les sites du nord-est des États-Unis. Nos résultats indiquent que le Merle d'Amérique (Turdus migratorius), la Paruline couronnée (Seiurus aurocapillus), la Grive fauve (Catharus fuscescens) et la Grive des bois (Hylocichla mustelina) ont un faible potentiel de dilution de la prévalence des infections de tiques, particulièrement lorsque les rongeurs sont présents à des densités moyennes ou fortes. Nous attribuons ce résultat au faible taux d'utilisation des oiseaux comme hôtes par les tiques et à la faible densité des oiseaux relativement à celle des rongeurs. Il n'y a que lorsque les rongeurs constituent moins de 10-20\% de la communauté d'hôtes (passereaux et rongeurs combinés) que les oiseaux sont capables de réduire substantiellement la prévalence des infections chez les tiques. Au cours des années ou dans les types d'habitats où la densité des rongeurs est faible, mais celle des passereaux qui nichent au sol est élevée, les risques d'exposition des humains à la maladie de Lyme peuvent se trouver réduits parce que les oiseaux diluent la prévalence des infections chez les tiques vectrices.

[Traduit par la Rédaction]

\section{Introduction}

Lyme disease is the most common vector-borne disease in North America, Europe, and parts of Asia, with thousands of cases reported annually (Lane et al. 1991; Barbour and Fish 1993; Humair et al. 1993; Miyamoto et al. 1993; Hubalek et al. 1995; Olsén et al. 1995). The etiologic agent of Lyme

Received March 31, 2000. Accepted September 11, 2000.

A.R. Giardina, K.A. Schmidt, E.M. Schauber, and R.S. Ostfeld. ${ }^{1}$ Institute of Ecosystem Studies, Box AB, Route 44A, Millbrook, NY 12545, U.S.A.

${ }^{1}$ Author to whom all correspondence should be addressed (e-mail: Rostfeld@ecostudies.org). disease, Borrelia burgdorferi, typically cycles between ticks (Ixodes scapularis (the black-legged tick) in eastern and central North America) and a variety of vertebrate hosts. Humans are exposed to Lyme disease when ticks use them, rather than a wildlife species, as hosts, potentially transmitting $B$. burgdorferi to the human host. The abundance and infection prevalence of ticks are critical risk factors in the Lyme disease epidemic (Barbour and Fish 1993).

Ixodes scapularis goes through 3 post-egg life stages: larva, nymph, and adult. During each stage, ticks take a single blood meal, lasting 2-7 days, from a vertebrate host. Because of poor transovarial transmission, larval ticks typically hatch free of Lyme spirochetes (Lane et al. 1991) and must acquire the infection through a blood meal from an infected vertebrate host. However, once acquired, B. burgdorferi in- 
fections persist through successive molts. Whether a juvenile (larva or nymph) tick will acquire B. burgdorferi, and hence be capable of transmitting Lyme disease to humans, is a function of the likelihood that the host will transmit the spirochetes to the feeding tick, i.e., the host's reservoir competence. In most cases, Lyme disease is transmitted by nymphs, although adults are responsible for some disease transmission (Barbour and Fish 1993).

Larval and nymphal stages of the black-legged tick are host generalists capable of parasitizing many mammalian, avian, and reptilian hosts (Anderson and Magnarelli 1984; Battaly et al. 1987; Anderson 1988; Manweiler et al. 1990; Magnarelli et al. 1992; Battaly and Fish 1993; Mannelli et al. 1993; Oliver et al. 1993; Brillhart et al. 1994; Levine et al. 1997). Vertebrate hosts vary tremendously in their reservoir competence (Mather et al. 1990; Mather 1993). In the eastern and central United States, white-footed mice (Peromyscus leucopus) and eastern chipmunks (Tamias striatus) are generally the most competent reservoirs for B. burgdorferi (Mather 1993; McLean et al. 1993; Slajchert et al. 1997; Schmidt and Ostfeld 2000) and the most abundant hosts of ticks (Mather 1993; Schmidt et al. 1999). Host communities dominated by mice and chipmunks are expected to contribute to high infection prevalence in the tick population. In contrast, the presence of a diverse community of hosts, most of which are poor or incompetent reservoirs for B. burgdorferi, should reduce infection prevalence in the population of hostseeking ticks, a phenomenon termed the dilution effect (Ostfeld and Keesing 2000; Schmidt and Ostfeld 2000).

Several species of ground-foraging and ground-nesting forest songbirds are common in areas of the northeastern United States (NE region) where Lyme disease is endemic. These species, including the American robin (Turdus migratorius), ovenbird (Seiurus aurocapillus), veery (Catharus fuscescens), and wood thrush (Hylocichla mustelina), have a higher probability of coming into contact with questing ticks than do more arboreal birds (Rand et al. 1998). Reservoir competence varies among these species. For instance, veeries have moderate reservoir competence, while the closely related wood thrush inefficiently transmits Lyme disease spirochetes (Anderson et al. 1986; Magnarelli et al. 1992). As a group, songbirds are much less likely to transmit $B$. burgdorferi than are the more competent rodent hosts (Appendix Table A1).

In this paper we explore the potential for common groundnesting and ground-foraging songbirds to influence the infection prevalence of black-legged ticks. We hypothesized that the presence of alternative hosts with low reservoir competence, such as songbirds, will reduce the infection prevalence of tick populations by reducing the proportion of ticks' blood meals taken from more competent hosts such as mice and chipmunks. The efficacy of songbirds in diluting infection prevalence will depend on the relative numbers of ticks that feed upon highly competent rodents versus poorly competent birds, which in turn depend on (i) the relative abundance of these hosts and (ii) tick burdens per host species. Because experimental manipulation of the abundance of rodents and songbirds and their tick burdens is not feasible, we used a modeling approach.

Our general strategy was to use empirically based models to predict the abundance and infection prevalence of blacklegged ticks in response to variation in the relative abundance of rodent and songbird hosts. To facilitate our examination of songbirds as potential "dilution hosts," we simplified host communities in the following ways. First, we assumed that the vertebrate community consists solely of rodents and songbirds. Although we know that other species of hosts occur in areas where Lyme disease is endemic, this simplification of the host community was necessary to isolate the effects of these two potentially important taxa on tick density and infection prevalence. Second, we examined the response of tick abundance and infection prevalence to a wide range of rodent densities. Rodent populations can fluctuate dramatically in response to changes in resource levels (Ostfeld et al. 1996; Wolff 1996), predator abundance (Hanski et al. 1993), and weather (Lewellen and Vessey 1998). Third, we assumed that densities of songbirds may be affected by densities of rodents (Ketterson et al. 1996).

A number of experimental field studies using natural and artificial nests reveal that mice and chipmunks are common predators on songbird eggs and nestlings (Maxson and Oring 1978; Guillory 1987; Haskell 1995; Hanski et al. 1996; Ketterson et al. 1996; Hannon and Cotterill 1998; Schmidt et al. 2001). For at least two ground-nesting species (dark-eyed juncos (Junco hyemalis) and wood warblers (Phylloscopus sibilatrix)), summer densities are significantly negatively correlated with those of mouse predators (Ketterson et al. 1996; Jędrzejewska and Jędrzejewski 1998). Although rodents may influence densities of ground-dwelling songbirds, there is no evidence to suggest that densities of forest songbirds influence those of rodents.

We use original and published data to evaluate the potential effects of birds as dilution hosts. We quantified population sizes and tick-infestation rates for the 2 most common species of rodents and 4 most common species of groundforaging, ground-nesting songbirds within an oak-forest site in Dutchess County, New York, and used these data to derive parameter values for our simulation model. The model was then used to examine the potential for songbirds to influence tick abundance, prevalence of $B$. burgdorferi in the tick population, and hence the risk of Lyme disease for humans across a range of natural densities of both rodent and avian hosts.

\section{Model description}

\section{Equations for ticks}

Our model incorporates the densities of hosts (rodents and birds), rates of infestation of hosts by ticks, and the reservoir competence of hosts in order to examine how fluctuating host communities, described in the Introduction, may influence tick abundance and infection prevalence. We calculate the number of larval and nymphal meals $\left(m_{1}\right.$ and $m_{\mathrm{n}}$, respectively) taken from the $i$ th host species ( $i=$ chipmunks $(\mathrm{C})$, mice $(\mathrm{M})$, American robins $(\mathrm{R})$, ovenbirds $(\mathrm{O})$, veeries $(\mathrm{V})$, and wood thrushes (W)) as the product of the host's density, $N_{i}$, and its mean tick burden:

$$
\begin{aligned}
& m_{1, i}=N_{i} B_{1, i} \\
& \text { [2] } \\
& m_{\mathrm{n}, i}=N_{i} B_{\mathrm{n}, i}
\end{aligned}
$$

where $B_{1}$ and $B_{\mathrm{n}}$ are the mean larval and nymphal tick burden, respectively, on the $i$ th host species. We make the simplifying assumption that larval and nymphal tick burdens on 
each host species are constant and independent of host or tick density. Mortality of larvae is reflected in the magnitudes of the tick-burden parameters estimated from the field. Many larvae will not survive to feed as nymphs over all possible host species, and thus $\Sigma B_{\mathrm{n}, i} \ll \sum B_{1, i}$. Furthermore, we assume that mortality of a tick is independent of whether or not it is infected with B. burgdorferi (R.S. Ostfeld, unpublished data).

We assume that infection prevalence in molted nymphs will be the same as in engorged larvae, and that all ticks which bite hosts survive to the next life stage. We calculate the number of nymphs infected from their larval meal on the $i$ th host species, $I_{\mathrm{n}, i}$, as the product of the number of larval meals obtained from the $i$ th host and the host's reservoir competence, $C_{i}$ :

\section{[3] $I_{\mathrm{n}, i}=m_{1, i} C_{i}$}

Similarly, the number of adults first infected, $I_{\mathrm{a}, i}$ from their nymphal meal on the $i$ th host species is equal to the product of the number of nymphal meals obtained from the $i$ th host species and the host species' reservoir competence. However, recall that $B$. burgdorferi is transmitted between all successive molts from an infected tick, therefore we must multiply the above product by the probability that the tick was not previously infected from its larval meal:

$$
I_{\mathrm{a}, i}=m_{\mathrm{n}, i} C_{i}\left\{1-\left[\left(\Sigma m_{1, i} C_{i}\right) / \Sigma m_{1, i}\right]\right\}
$$

Finally, we calculate the total number of adults infected from either their larval or nymphal meal from all hosts:

$$
I_{\mathrm{T}}=\Sigma I_{\mathrm{n}, i}+\sum I_{\mathrm{a}, i}
$$

\section{Equations for songbirds}

We use the model of Schmidt and Whelan (1999) to incorporate the influence of nest predation by mice and chipmunks on annual fecundity of songbirds. The density of adults of the $i$ th species is estimated as $\alpha_{i}$. We assumed that all adults were paired (1:1 sex ratio) and attempted to breed. The cumulative density of adults and juveniles of the $i$ th species is given as

$$
\begin{aligned}
N_{i}=\alpha_{i}+ & \left(\alpha_{i} / 2\right)\left\{J_{i}\left(1-F_{i}\right)\right. \\
& \left.+d_{i} J_{i}\left(1-F_{i}\right)^{2}+\sum_{j=1}^{v}\left[F_{i}^{j} k_{i} J_{i}\left(1-F_{i}\right)\right]\right\}
\end{aligned}
$$

where $J$ is the mean number of juveniles produced per successful nest, and $F$ is the probability of nest failure due to predation (the only source of nest mortality included in the model). Equation 6 also assumes that all pairs, $\alpha / 2$, attempt at least 1 nest and that if this first attempted nest is depredated they will renest with probability $k$, to a maximum of $v$ attempts. Following Schmidt and Whelan (1999), only pairs that were successful on their first nesting attempt were allowed to attempt a second nest with probability $d$. Because American robins have a longer breeding season than the other 3 species, which migrate to the breeding grounds from the Neotropics, we modified eq. 6 so that robins had a maximum of 4 nesting attempts in which to produce a maximum of 2 broods. To estimate $F$, we assumed that nest predation is a linear function of rodent density (see the next section).

\section{Methods and parameterization of the model}

We used field data specific to our study site, as well as published values for the NE region, to parameterize our model. Our field study was conducted on the property of the Institute of Ecosystems Studies (IES) in Dutchess County, New York $\left(41^{\circ} 50^{\prime} \mathrm{N}, 73^{\circ} 45^{\prime} \mathrm{W}\right)$ within six 2.7 -ha plots. The tree canopy of these forest plots is dominated by oak species (Quercus rubra and Quercus prinus), while the understory is made up of oak saplings, sugar maple (Acer saccharum), eastern hemlock (Tsuga canadensis), and maple-leaved viburnum (Viburnum acerifolium).

\section{Rodent tick burden, tick density, and reservoir competence}

On 3 of the plots, rodent densities were experimentally manipulated in 1998 for purposes unrelated to this study. We used unmanipulated control plots only $(N=3)$ in calculating rodent densities and rodent tick burdens. On each plot, whitefooted mice and chipmunks were livetrapped monthly for 2 or 3 consecutive days between late May and early November (for detailed trapping methods see Jones et al. 1998). The first time each individual rodent was captured during a 2- to 3-day trapping session, we counted all the larvae and nymphs attached to the its head and ears, which approximates its total tick burden (Schmidt et al. 1999). Mean tick burdens (excluding data obtained after August) are given in Table 1.

We calculated the density of white-footed mice as the minimum number known to be alive (MNA). The high capture probability for individual mice made MNA an accurate method of calculating mouse densities. To reduce the number of unconstrained parameters in our model, we set chipmunk density at half that of the mouse population to reflect the tight correlation, with a slope of 0.5 , between the two rodent densities measured at IES over the previous 4 years (Schmidt et al. 1999). Therefore, in our model, when we explicitly vary white-footed mouse density from 0 to $100 /$ ha, chipmunk densities vary proportionately from 0 to $50 / \mathrm{ha}$. Reservoir competence for mouse and chipmunk populations at IES was taken from Schmidt and Ostfeld (2000; Table 1).

\section{Songbird density and nesting parameters}

To estimate the density of adult songbirds $(\alpha)$ on our study plots, we counted the singing adult males of each species on each of the 6 plots, using the point-count method (Bibby et al. 1992). We counted all birds heard within in a 40-m radius over a 5-min time interval at 3 points on each plot. Counts were conducted between 07:00 and 12:00 once a week for 4 consecutive weeks in late June and early July 1998. We randomized the order in which the plots were visited among weeks. We estimated adult density for each species as the maximum number of singing males recorded in any one week multiplied by 2 (Table 2). To allow for the possibility that our point counts overestimated bird density, e.g., if some singing males were not mated, we cross-checked point-count estimates against those based on mist-netting and nest counts (K.A. Schmidt, A.R. Giardina, and R.S. Ostfeld, unpublished data). The latter data suggested that point-count estimates for American robins and ovenbirds are probably accurate, but those for wood thrushes and veeries are probably inflated. We used sensitivity analyses to account for the potential effects of density overestimation (see below). 
Table 1. Larval and nymphal tick burdens on and reservoir competence of each host species at the Institute of Ecosystem Studies (IES) and in the northeastern U.S.A. (NE).

\begin{tabular}{|c|c|c|c|c|c|c|c|}
\hline \multicolumn{2}{|l|}{ Host species } & \multicolumn{2}{|c|}{$\begin{array}{l}\text { No. of } \\
\text { larvae/individual }\left(B_{1}\right)^{a}\end{array}$} & \multicolumn{2}{|c|}{$\begin{array}{l}\text { No. of } \\
\text { nymphs/individual }\left(B_{\mathrm{n}}\right)^{a}\end{array}$} & \multicolumn{2}{|c|}{$\begin{array}{l}\text { Reservoir } \\
\text { competence }(C)\end{array}$} \\
\hline Common name & Scientific name & IES & $\mathrm{NE}$ & IES & $\mathrm{NE}$ & IES & NE \\
\hline American robin & Turdus migratorius & $1.00(0.37)$ & 1.21 & $9.67(2.44)$ & 1.74 & na & 0.200 \\
\hline Ovenbird & Seiurus aurocapillus & $0.18(0.09)$ & 3.46 & $1.78(0.39)$ & 0.15 & na & 0.011 \\
\hline Veery & Catharus fuscescens & $0.18(0.09)$ & 1.26 & $1.78(0.39)$ & 1.59 & na & 0.285 \\
\hline Eastern chipmunk & Tamias striatus & $4.19(0.88)$ & 3.93 & $4.90(0.60)$ & 4.00 & 0.687 & 0.286 \\
\hline White-footed mouse & Peromyscus leucopus & $9.65(0.54)$ & 9.45 & $0.68(0.07)$ & 0.72 & 0.935 & 0.629 \\
\hline
\end{tabular}

${ }^{a}$ Values are given as the mean, with the standard error in parentheses; na, not applicable.

To estimate the number of juveniles produced per successful nest, $J$, we used the average clutch size for each species taken from Ehrlich et al. (1988), Moskoff (1995), and Roth et al. (1996) (Table 2), which assumes no in-nest mortality, including parasitism from cowbirds. We estimated the probability of double-brooding, $d$, for each species using Ehrlich et al. (1988), Trine (1998), Moskoff (1995), and Roth et al. (1996) as our sources (Table 2). The number of renests attempted, $v$, and the probability of renesting, $k$, were estimated from Schmidt and Whelan (1999) (Table 2).

To determine the relationship between rodent density and nest-predation rates, we assumed a linear relationship between rodent density and nesting success (Ketterson et al. 1996). We used our field data on rodent densities and success rates of natural nests of American robins, ovenbirds, veeries, and wood thrushes (K.A. Schmidt, A.R. Giardina, and R.S. Ostfeld, unpublished data) to estimate the slopes and $y$ intercepts of regression lines. Nests of the 4 songbird species vary in their vulnerability to predation by rodents, owing to differences in adult body size and nest location. Predation on robin and ovenbird nests appears to be independent of rodent density at our sites, therefore we used a slope of 0 for these species. For veeries and wood thrushes we estimated the slope using the difference between the years of lowest and highest mouse densities (4 and 40 mice/ha in 1996 and 1998, respectively). In the case of veeries, for example, nest-predation rates in the years of low and high mouse densities were 36 and $89 \%$, respectively, giving us a slope of $(0.89-0.36) / 90=0.006$. We then back-calculated the intercept (i.e., nest predation expected when no mice were present) from the year of extremely low mouse density: $0.36-(10 \times 0.006)=0.30$. The results of these calculations for the 4 bird species are shown in Table 2. Because of the potential for estimation errors, we performed a sensitivity analysis on all parameters in eq. 6.

\section{Songbird tick burdens}

We captured birds in mist nets $(12 \times 3 \mathrm{~m})$ during June and July 1998. Nets were opened between 07:00 and 11:00 on each plot approximately once a week for 6 weeks. Periodically, recordings of each species' song and call were played at the base of a net to attract birds. At first capture, we banded each individual with an aluminum U.S. Fish and Wildlife Service leg band for later identification. For each individual, we recorded species, band number, age, gender, body mass, location, and the lengths of the wing cord, beak, and tarsus. We carefully examined the head and legs of each bird and recorded the number of attached larvae and nymphs. We considered recaptures made more than 5 days apart (the maximum length of a juvenile tick meal) to be independent samples of tick burdens on hosts. Only 3 birds were recaptured and reexamined during our study.

\section{Regional analysis}

To extend our local analyses to the NE region, we took the average, weighted by sample size, of each host species' reservoir competence $\left(C_{i}\right)$, larval burden $\left(B_{1, i}\right)$, and nymphal burden $\left(B_{\mathrm{n}, i}\right)$ from published sources (Appendix Tables A1 and A2). We used values of $C_{\mathrm{R}}, C_{\mathrm{O}}, C_{\mathrm{V}}$, and $C_{\mathrm{W}}$ averaged for the NE region in the IES analysis because the reservoir competence of these bird species has not been measured at IES. We used $N_{\mathrm{R}}, N_{\mathrm{O}}, N_{\mathrm{V}}$, and $N_{\mathrm{W}}$ values calculated for IES in the NE region analysis because these values are not known for these 4 species for the NE region.

\section{Results}

\section{Parameter values for IES: tick burdens and reservoir competence}

Burdens of juvenile ticks ranged from 0 to 3 larvae/bird and from 0 to 17 nymphs/bird. We used ANOVA to test for differences between species and plots for both larval and nymphal burdens on songbirds. Nymphal burdens differed significantly among species $\left(F_{[3,60]}=13.61, P<0.01\right)$, but larval burdens did not $\left(F_{[3,60]}=2.64, P=0.06\right)$. There were no significant differences among plots (larval burdens: $F_{[2,60]}=1.63, P=0.20$; nymphal burdens: $F_{[2,60]}=15.99$, $P=0.23)$. American robins tended to have a significantly higher burden of both tick larvae and nymphs than did the other species (Tukey's test, larvae: 2 of 3 pairwise comparisons, $P \leq 0.05$; nymphs: 3 of 3 comparisons, $P<0.001)$. The larval and nymphal burdens on ovenbirds, veeries, and wood thrushes were not significantly different from one another (Tukey's test, larvae: 3 of 3 comparisons, $P>0.90$; nymphs: 3 of 3 comparisons, $P>0.15)$. Based on this analysis, we used the values for American robins $(1.00 \pm 0.37$ (mean \pm 1 SE) larvae/robin and $9.67 \pm 2.44$ nymphs/robin) and pooled the remaining species $(0.18 \pm 0.09$ larvae/bird and $1.78 \pm$ 


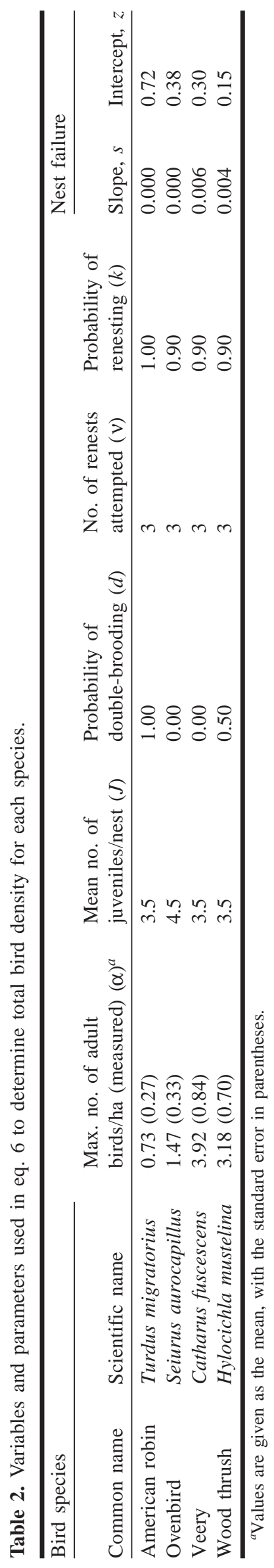

0.39 nymphs/bird; Table 1). Burdens on rodents were $4.19 \pm$ 0.88 larvae/chipmunk, $9.65 \pm 0.54$ larvae/mouse, $4.90 \pm$ 0.60 nymphs/chipmunk, and $0.68 \pm 0.07$ nymphs/mouse. Reservoir competence for rodents was estimated as the proportion of larval ticks feeding from a host that molted into an infected nymph: 0.687 for chipmunks and 0.935 for mice (Schmidt and Ostfeld 2000; Table 1).

\section{Parameter values for IES: host densities}

Densities of adult birds, averaged over all plots, varied from 0.73 to $3.92 /$ ha depending on the species (Table 2). The remaining parameters, taken from the literature, are given in Table 2. To estimate the sensitivity of total bird density (adults plus fledged juveniles) to errors in our parameter values, we performed a sensitivity analysis by adjusting parameters from eq. $6(\alpha, J, d, v, k, s$, and $z$ ) by $\pm 10 \%$ (because the number of renesting attempts was an integer value, we varied it by \pm 1 ). To mimic 3 levels of predation on nests, we allowed rodent densities to vary among 3 categories: low, medium, and high. Over all the bird species, life-history parameters, and rodent densities, the percent change in total bird density was almost always $<10 \%$ and usually $<3 \%$. Total bird density was most sensitive to changes in the number of juveniles per successful nest, particularly for robins (change in the number of birds per hectare ranged from -12.9 to $+6.5 \%$ ), which frequently double-brood, and for ovenbirds (range -7.8 to $+8.5 \%$ ), which have the highest nesting success. Robins were similarly sensitive (range -15.2 to $+12.0 \%$ ) to varying the nest-failure intercept. For veeries and wood thrushes, varying the density of adult birds and number of juveniles per nest produced a change of approximately $5 \%$ in total bird density, while varying other parameters produced a change of $<5 \%$ in total bird density over all 3 rodent densities. To summarize, our sensitivity analysis revealed that total bird density is relatively insensitive to changes in the parameters used to calculate seasonal fecundity across a wide range of rodent densities. These changes become even less significant when one considers the impact of songbirds on tick numbers and infection prevalence (see "Model results" below).

\section{Parameter values for the NE region: tick burdens and reservoir competence}

Our literature review for the NE region revealed that mean larval burdens on ground-dwelling songbirds ranged from 1.04 to 3.46/bird, while rodent larval burdens were 3.93/ chipmunk and 9.45/mouse (Table 1). Mean nymphal burdens were 0.15-1.74/bird, 4.00/chipmunk, and 0.72/mouse. Average reservoir competence values (weighted averages) for birds were very low to moderate, falling between 0.003 and 0.285 , whereas average values for rodents were 0.286 (chipmunks) and 0.629 (mice). For the regional analysis, we entered the same values in eq. 6 as in the IES analysis (Table 2).

\section{Model results}

As rodent density (mice plus chipmunks) increased from 0 to $150 /$ ha, total density of the 4 species of birds fell by $61 \%$, from 28 to 11 individuals/ha (Fig. 1). This resulted in a major shift in the relative abundance of bird versus rodent hosts for ticks. At IES, chipmunks and mice were responsible for virtually all the larval meals and nymphs infected (Fig. 2A). 
Fig. 1. Expected density of birds as a function of rodent density at the Institute of Ecosystem Studies (IES) in Millbrook, N.Y. (model output from eq. 6). "Density of rodents" (mice plus chipmunks) is used on the $x$ axis for consistency with the other figures; however, the relationship between nest failure and rodent density is based on white-footed mice (Peromyscus leucopus) alone.

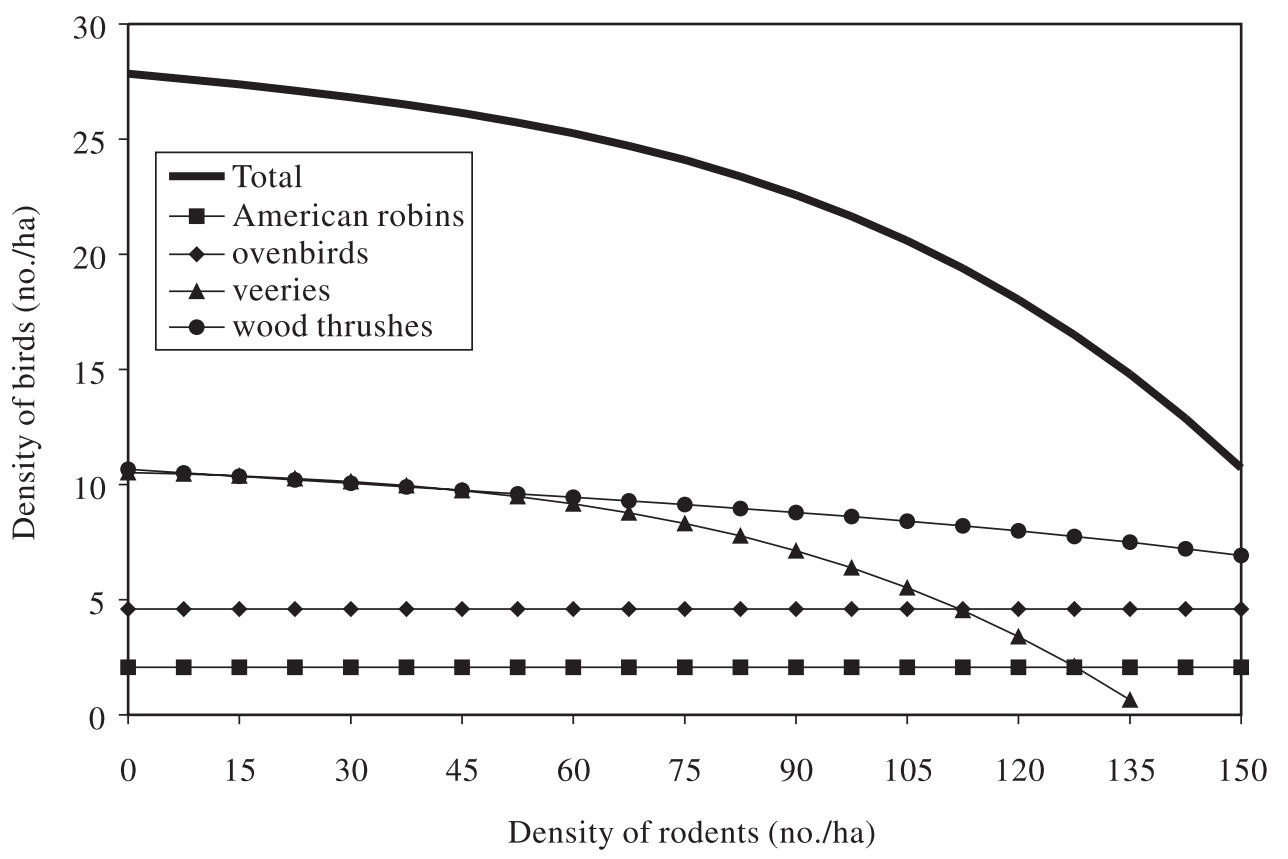

Across the range of rodent densities, larval meals from rodents and number of nymphs infected from rodents rose from 0 to $>1000 /$ ha. In contrast, over the same rodentdensity gradient, the number of larval meals from birds fell from 7 to 5.4/ha and the number of nymphs infected from birds fell from 1 to $0.3 /$ ha. A similar, though not as dramatic, trend was evident in the percentage of nymphal meals and adults infected during their nymphal meals from rodents versus birds (Fig. 2B).

The trends at IES were repeated for the NE region, although the results differed somewhat in magnitude (Fig. 3). Over the same rodent-density gradient, larval meals from rodents rose from 0 to $>1000 /$ ha, and the number of nymphs infected from rodents rose from 0 to $650 /$ ha. In contrast, larval meals from birds fell from 43 to $2 /$ ha and the number of nymphs infected from birds fell from 4 to $<1 /$ ha. The number of nymphal meals obtained from rodents rose from 0 to $272 /$ ha and the number of adults infected from their nymphal meal on rodents rose from 0 to $44 /$ ha. The number of nymphal meals from birds fell from 23 to $1 /$ ha and the number of adults infected from their nymphal meal on birds fell from 5 to $<1 /$ ha.

At IES, $15 \%$ of nymphs would be infected after feeding as larvae from a host community in which rodents are absent (Fig. 4A). Nymphal infection prevalence rose quickly until the host community consisted of about $10 \%$ rodents, above which $>70 \%$ of nymphs were infected. We found a similar pattern in the percentage of adults infected from either their larval or nymphal meal. In a host community without rodents, $27 \%$ of adult ticks would be infected. This percentage rose quickly until the host community consisted of about $15 \%$ rodents, above which $>80 \%$ of adults were infected.

For the NE region, in a host community without rodents, $10 \%$ of nymphal ticks and $32 \%$ of adult ticks would be infected (Fig. 4B). These percentages rose quickly until the host community consisted of about $20 \%$ rodents, above which $>35 \%$ of nymphs and $>55 \%$ of adults would be infected.

\section{Discussion}

The community composition of hosts of black-legged ticks is an important factor determining tick abundance and prevalence of infection with Lyme disease bacteria. Small rodents, such as the white-footed mouse and eastern chipmunk, play an important role in the ecology of Lyme disease by supporting a large tick population with high infection prevalence (Mather 1993; Ostfeld 1997). In this study we evaluated the potential of birds as alternative hosts to dilute the infection prevalence of ticks. Our results indicate that ground-foraging and ground-nesting forest songbirds (e.g., American robins, ovenbirds, veeries, and wood thrushes) generally have a low capacity to dilute tick infection prevalence in oak forests of the northeastern United States. The dilution capacity of birds is low because rodents tend to outnumber birds and have higher tick burdens (although exceptions occur at individual sites; see Appendix Table A2) and higher reservoir competence than birds.

However, the model revealed that when rodents constitute less than 10-20\% of the host community, the infection prevalence of both nymphal and adult ticks declines dramatically (Fig. 4). Therefore, our results suggest that at sites or in years when rodents are scarce or birds are abundant, the risk of human exposure to Lyme disease should diminish. These conditions may be met in spatially and temporally varying vertebrate communities. Because of fluctuating acorn production, the density of white-footed mice and eastern chipmunks in summer may vary by $>1$ order of magnitude among years, reaching nadirs of <10/ha (Elkinton et al. 1996; Ostfeld et al. 1996, 1998; Wolff 1996; Ostfeld 1997). With the consequent release from nest predation by rodents, densities of 
Fig. 2. Expected numbers of larval-tick meals and nymphal ticks becoming infected from their larval meal per hectare when those meals are taken from rodents and birds. Parameter values for the model were taken from data obtained at IES. (A) Model output from eqs. 1 and 3. (B) Model output from eqs. 2 and 4.
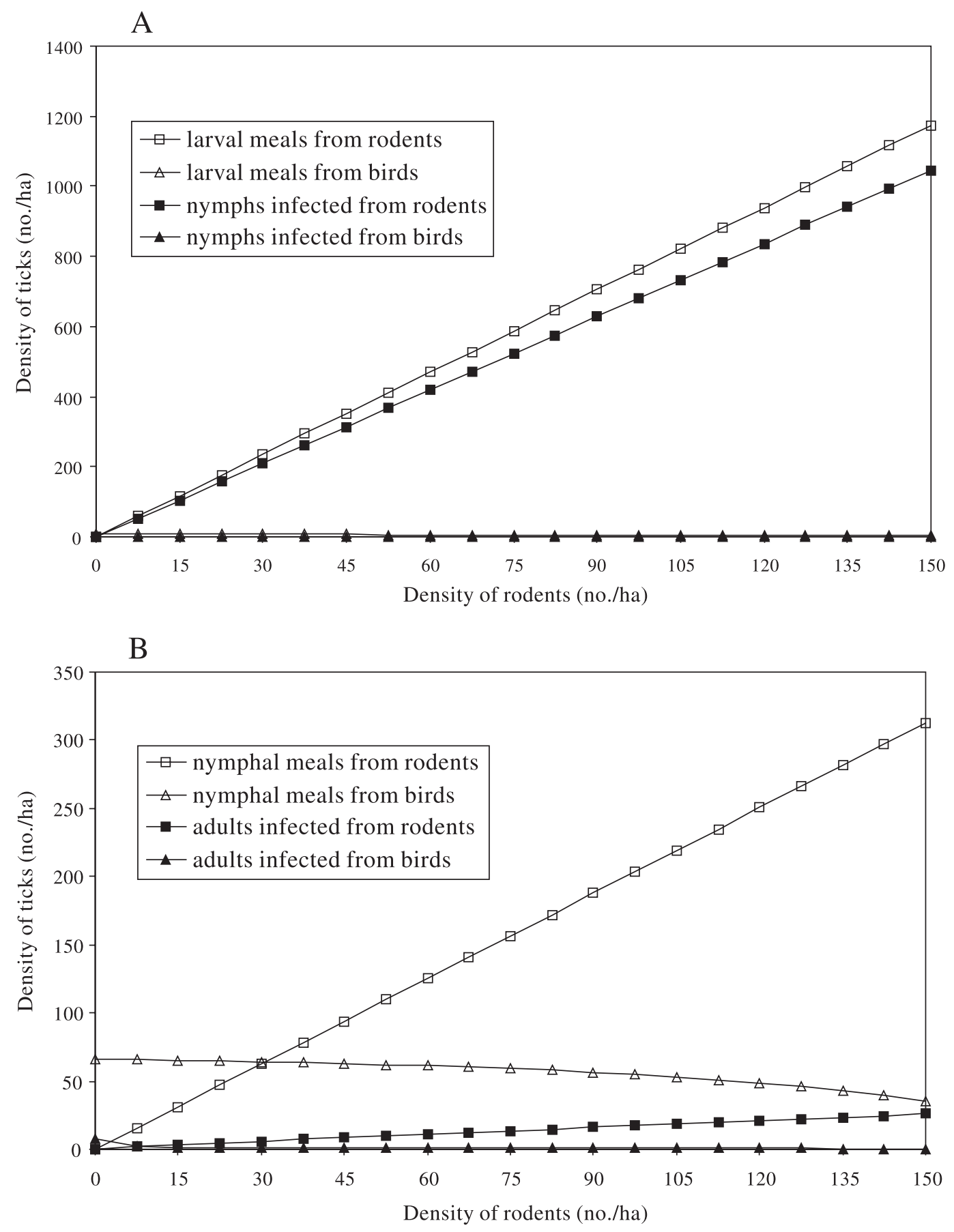

adult plus juvenile ground-dwelling birds are expected to peak at about 30 individuals/ha. Thus, we expect that in years of episodic crashes in rodent populations, birds may effectively dilute the strong positive effect of rodents on infection prevalence of ticks. Similarly, densities of rodent versus avian hosts may vary dramatically among habitat types within a region. For example, American robins are relatively uncommon in forest interiors but common in residential areas. In addition, some habitat types may be occupied by dif- ferent species of ground-dwelling birds (e.g., towhees (Pipilo erythrophthalmus) and gray catbirds (Dumetella carolinensis)) that vary in tick burdens and reservoir competence. The predictions of our model should be tested by determining relative densities of rodents and birds in residential areas, where many cases of Lyme disease occur (Barbour and Fish 1993).

Changes in tick infection prevalence with changing proportions of rodents were more dramatic for the model parameterized for our local site at IES than for the model 
Fig. 3. Expected numbers of larval-tick meals and nymphal ticks becoming infected from their larval meal per hectare when those meals are taken from rodents and birds. Parameter values for the model were taken from data obtained during studies conducted throughout the northeastern United States. (A) Model output from eqs. 1 and 3. (B) Model output from eqs. 2 and 4.
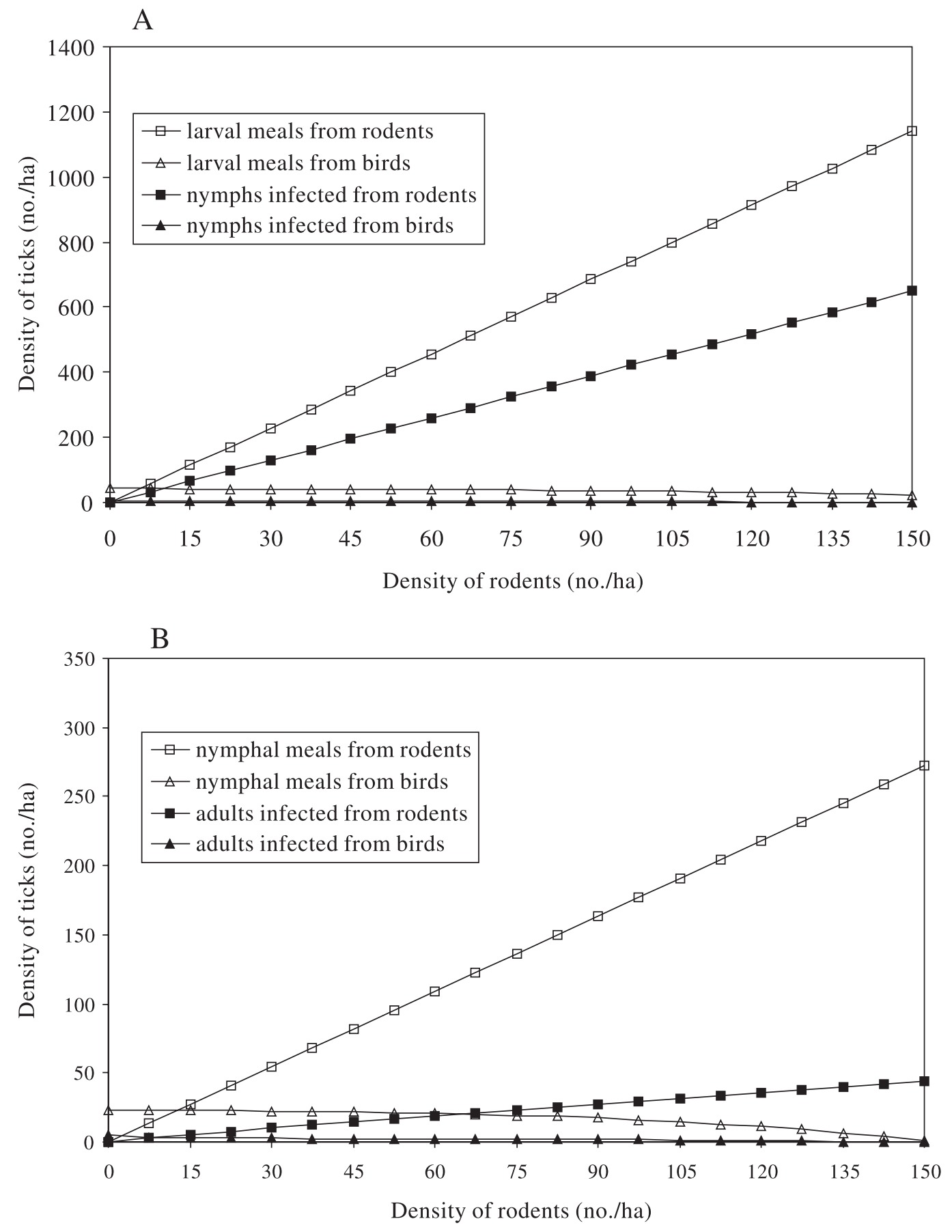

parameterized for the NE region (Fig. 4). The main reason for the difference between IES and the NE region appears to be the higher reservoir competence of rodents at IES (Table 1). In contrast, although tick burdens on birds differed between IES and the NE region, all values were relatively low, as were those for the reservoir competence of birds. A recent study by Richter et al. (2000) indicates that the reservoir competence of American robins is high shortly after inoculation by infected ticks and declines dramatically over the next 1-3 months. Such temporal changes in reservoir competence complicate the estimation of host-specific infectivity, which is assumed to be insensitive to time since inoculation. The high reservoir competence of IES rodents had three consequences for the IES simulation relative to the NE region: (1) nymphal and adult infection prevalence reached higher asymptotes; (2) nymphal and adult infection prevalence values were similar in magnitude; and (3) there was a distinct threshold when rodents made up ca. $10 \%$ of the host 
Fig. 4. Percentages of ticks infected from a host community consisting of chipmunks, white-footed mice, American robins, ovenbirds, veeries, and wood thrushes, based on model output from eqs. 3 and 5. (A) The model parameterized for IES. (B) The model parameterized for the northeastern United States.
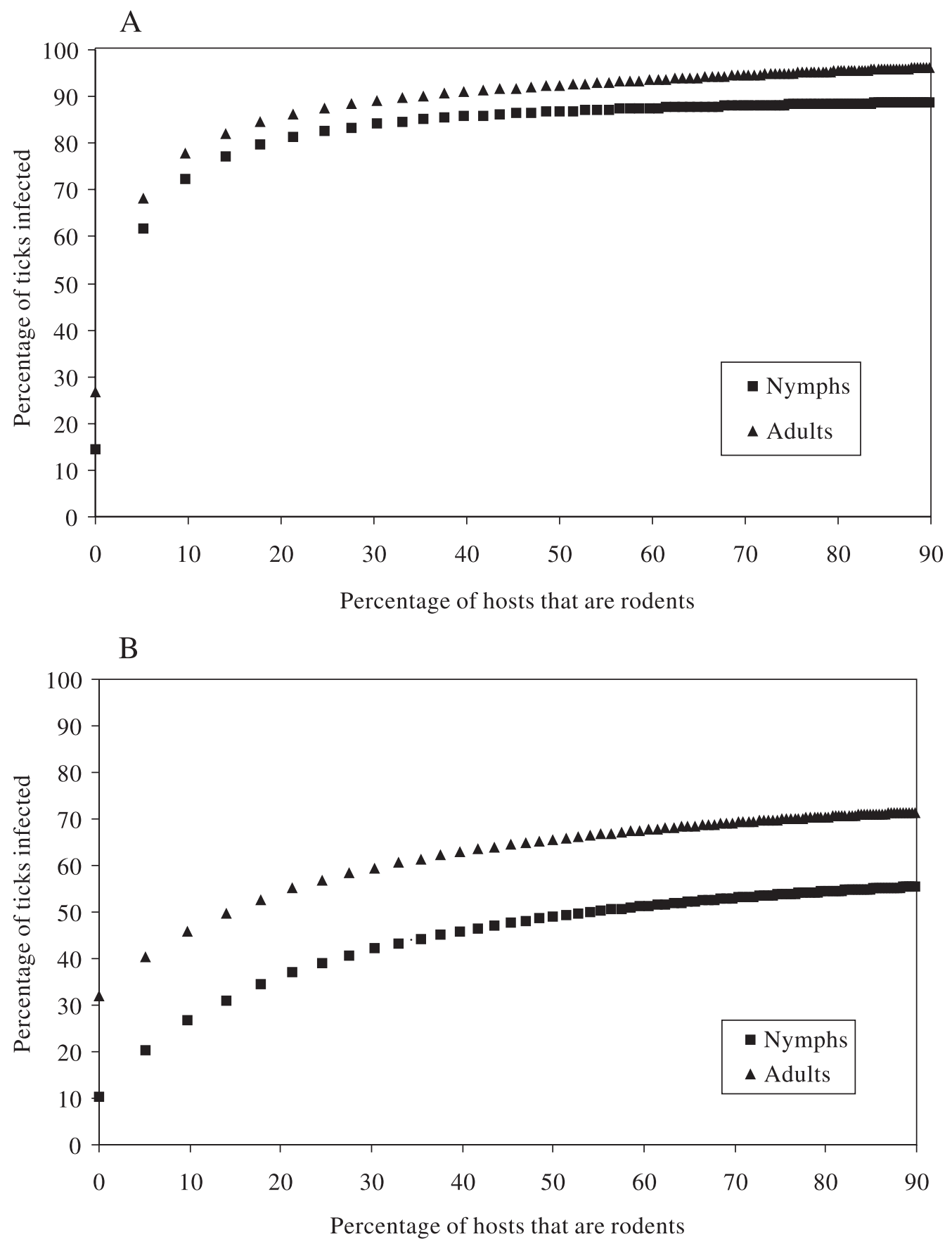

community, below which there was an accelerating decline in tick infection prevalence. In contrast, the decline in infection prevalence was much more gradual for the NE region.

The veracity of some of our model's assumptions should be evaluated. Relaxing our assumption of constant tick burdens irrespective of variation in densities of hosts or hostseeking ticks may influence the model outcome. However, the relationships between tick burdens and densities of either hosts or host-seeking ticks are inconsistent between sites and years (Schmidt et al. 1999), so we expect any effects to be modest or temporary. Furthermore, tick burdens do not change with host density in ways that are consistent with a model of passive encounter between a host-seeking tick and its host (Schmidt et al. 1999). Similarly, the assumption that the reservoir competence of each host species is fixed and independent of that of other hosts has not been validated, and is probably inaccurate (Richter et al. 2000). It is not obvious how relaxing this assumption would affect the model outcome.

A key goal of our studies is to understand how variation in the composition of communities of tick hosts will influence tick infection prevalence and disease risk. In this modeling 
study we simplified the vertebrate community by including only the most prominent rodent and songbird hosts, and effectively holding constant the abundance of other hosts. Although some other mammalian hosts, such as deer, tree squirrels, and raccoons, are parasitized commonly by blacklegged ticks, data are insufficient to quantify their contribution to the feeding of immature ticks and allow us to include them in models similar to those developed here. In addition, other ground-dwelling birds such as worm-eating warblers (Helmitheros vermivorus), gray catbirds, towhees, and blackand-white warblers (Mniotilta varia) may be important in some areas, but these species occurred at very low densities in IES forests $(<0.25 /$ ha; personal observations). Wild turkeys (Meleagris gallopavo) are common at our study sites; however, Ostfeld and Lewis (1999) found that they are poor hosts of larval and nymphal black-legged ticks. Because birds become relatively common hosts only after episodic crashes in rodent populations, other alternative hosts are likely important determinants of Lyme disease infection prevalence during years of moderate to high rodent density.

In conclusion, it is becoming increasingly evident that a diverse host community is important in diluting tick infection. Ostfeld and Keesing (2000) discovered that in regions with a large number of small-mammal and lizard species, cases of Lyme disease reported per capita tend to be fewer. Schmidt and Ostfeld (2000) found that the tick infection prevalence observed at our IES sites was dramatically lower than that expected when mice and chipmunks are the only primary hosts. They attributed this to the existence of an alternative community of hosts that collectively have a much lower reservoir competence than mice and chipmunks. In this study we have investigated the possibility that grounddwelling songbirds have the potential to dilute the infection prevalence of ticks. Our results indicate that only in habitat types where densities of songbirds are high relative to those of rodents, or in years of rodent scarcity, would birds be expected to be important in reducing the risk of Lyme disease. The role of non-mouse, non-chipmunk mammalian hosts remains to be evaluated theoretically and empirically. As more information becomes available regarding the densities, tick burdens, and reservoir competence of other hosts, our modeling approach can be adapted to incorporate more complete vertebrate communities. A key goal will be to understand the consequences of varying vertebrate diversity in space and time for the risk of human exposure to this disease.

\section{Acknowledgements}

We are grateful for the help of many field assistants, especially Jacob Goheen, David Lewis, and Bonnie Baker, in data collection and analysis. This research was supported by the National Science Foundation (grants DEB 9615414 and BIR 9322283), the National Institutes of Health (grant R01 AI40076), and the Research Experiences for Undergraduates program at the Institute of Ecosystem Studies. This paper is a contribution to the program of the Institute of Ecosystem Studies.

\section{References}

Anderson, J.F. 1988. Mammalian and avian reservoirs for Borrelia burgdorferi. Ann. N.Y. Acad. Sci. pp. 180-191.
Anderson, J.F., and Magnarelli, L.A. 1984. Avian and mammalian hosts for spirochete-infected ticks and insects in a Lyme disease focus in Connecticut. Yale J. Biol. Med. 57: 627-641.

Anderson, J.F., Johnson, R.C., Magnarelli, L.A., and Hyde, F.W. 1986. Involvement of birds in the epidemiology of Lyme disease agent Borrelia burgdorferi. Infect. Immun. 51: 394-396.

Anderson, J.F., Magnarelli, L.A., and Stafford, K.C., III. 1990. Bird-feeding ticks transstadially transmit Borrelia burgdorferi that infect Syrian hamsters. J. Wildl. Dis. 26: 1-10.

Barbour, A.G., and Fish, D. 1993. The biological and social phenomenon of Lyme disease. Science (Washington, D.C.), 260: 1610-1616.

Battaly, G.R., and Fish, D. 1993. Relative importance of bird species as host for immature Ixodes dammini (Acari: Ixodidae) in a suburban residential landscape of Southern New York State. J. Med. Entomol. 30: 740-747.

Battaly, G.R., Fish, D., and Dowler, R.C. 1987. The seasonal occurrence of Ixodes dammini and Ixodes dentatus (Acari: Ixodidae) on birds in a Lyme disease endemic area of southeastern New York State. J. N.Y. Entomol. Soc. 95: 461-468.

Bibby, C.J., Burgess, N.D., and Hill, D.A. 1992. Bird census techniques. Academic Press, London.

Brillhart, D.E., Fox, L.B., and Upton, S.J. 1994. Ticks (Acari: Ixodidae) collected from small and medium-sized Kansas mammals. J. Med. Entomol. 31: 500-504.

Davidar, P., Wilson, M., and Ribeiro, J.M.C. 1989. Differential distribution of immature Ixodes dammini (Acari: Ixodidae) on rodent hosts. J. Parasitol. 75: 898-904.

Ehrlich, P.R., Dobkin, D.S., and Wheye, D. (Editors). 1988. The birder's handbook. Simon \& Schuster Inc., New York.

Elkinton, J., Healy, W.M., Buonaccorsi, J.P., Hazzard, A.M., Smith, H.R., and Liebold, A.M. 1996. Interactions among gypsy moths, white-footed mice, and acorns. Ecology, 77: 2332-2342.

Fish, D., and Daniels, T.J. 1990. The role of medium-sized mammals as reservoirs of Borrelia burgdorferi in southern New York. J. Wildl. Dis. 26: 339-345.

Guillory, H.D. 1987. Cavity competition and suspected predation on prothonotary warblers by Peromyscus spp. J. Field Ornithol. 58: $425-427$.

Hannon, S.J., and Cotterill, S.E. 1998. Nest predation in aspen woodlots in an agricultural area in Alberta: the enemy from within. Auk, 115: 16-25.

Hanski, I., Turchin, P., Korpimäki, E., and Henttonen, H. 1993. Population oscillations of boreal rodents: regulation by mustelid predators leads to chaos. Nature (Lond.), 364: 232-235.

Hanski, I.K., Fenske, T.J., and Niemi, G.J. 1996. Lack of edge effects in nesting success of breeding birds in managed forest landscapes. Auk, 113: 578-585.

Haskell, D.E. 1995. A reevaluation of the effects of forest fragmentation on rates of bird-nest predation. Conserv. Biol. 9: 13161318.

Hubalek, Z., Juricova, Z., and Halouzka, J. 1995. A survey of freeliving birds as hosts and 'lessors' of microbial pathogens. Folia Zool. 44: 1-11.

Humair, P.F., Turrian, N., Aeschlimann, A., and Gern, L. 1993. Ixodes ricinus immatures on birds in a focus of Lyme borreliosis. Folia Parasitol. 40: 237-242.

Jędrzejewska, B., and Jędrzejewski, W. 1998. Predation in vertebrate communities: the Bialowieza Primeval Forest as a case study. Springer-Verlag, Berlin.

Jones, C.G., Ostfeld, R.S., Richard, M.P., Schauber, E.M., Wolff, J.O. 1998. Chain reactions linking acorns to gypsy moth outbreaks and Lyme disease risk. Science (Washington, D.C.), 279: 1023-1026. 
Ketterson, E.D., Nolan, V., Jr., Cawthorn, M.J., Parker, P.G., and Ziegenfus, C. 1996. Phenotypic engineering: using hormones to explore the mechanistic and functional bases of phenotypic variation in nature. Ibis, 138: 70-86.

Lane, R.S., Piesman, J., and Burgdorfer, W. 1991. Lyme borreliosis: relation of its causative agent to its vectors and hosts in North America and Europe. Annu. Rev. Entomol. 36: 587-609.

Levine, J.F., Apperson, C.S., Howard, P., Washburm, M., and Braswell, A.L. 1997. Lizards as hosts for immature Ixodes scapularis (Acari: Ixodidae) in North Carolina. J. Med. Entomol. 34: 594-598.

Lewellen, R.H., and Vessey, S.H. 1998. The effect of density dependence and weather on population size of a polyvoltine species. Ecol. Monogr. 68: 571-594.

Magnarelli, L.A., Anderson, J.F., Burdorfer, W., and Chappel, W.A. 1984. Parasitism by Ixodes dammini (Acari: Ixodidae) and antibodies to spirochetes in mammals at Lyme disease foci in Connecticut, U.S.A. J. Med. Entomol. 21: 52-57.

Magnarelli, L.A., Stafford, K.C., III, and Bladen, V.C. 1992. Borrelia burgdorferi in Ixodes dammini (Acari: Ixodidae) feeding on birds in Lyme, Connecticut, U.S.A. Can. J. Zool. 70: 2322-2325.

Mannelli, A., Kitron, U., Jones, C.J., and Slajchert, T.L. 1993. Ixodes dammini (Acari: Ixodidae) infection on medium-sized mammals and blue jays in northwestern Illinois. J. Med. Entomol. 34: 594-598.

Manweiler, S.A., Lane, R.S., Block, W.M., and Morrison, M.L. 1990. Survey of birds and lizards for ixodid ticks and spirochetal infection in northern California. J. Med. Entomol. 27: 1011-1015.

Mather, T.N. 1993. The dynamics of spirochete transmission between ticks and vertebrates. In Ecology and environmental management of Lyme disease. Edited by H. Ginsberg. Rutgers University Press, New Brunswick, N.J. pp. 43-60.

Mather, T.N., Telford, S.R., III, MacLachlan, A.B., and Spielman, A. 1989a. Incompetence of catbirds as reservoirs for the Lyme disease spirochete (Borrelia burgdorferi). J. Parasitol. 75: 6669.

Mather, T.N., Wilson, M.L., Moore, S.I., Ribeiro, J.M.C., and Spielman, A. 1989b. Comparing the relative potential of rodents as reservoirs of the Lyme disease spirochete (Borrelia burgdorferi). Am. J. Entomol. 130: 143-150.

Mather, T.N., Tellford, S.R., III, Moore, S.I., and Spielman, A. 1990. Borrelia burgdorferi and Babesia microti: efficiency of transmission from reservoirs to vector ticks (Ixodes dammini). Exp. Parasitol. 70: 55-61.

Maxson, S.J., and Oring, L.W. 1978. Mice as a source of egg loss among ground-nesting birds. Auk, 95: 582-584.

McLean, R.G., Ubico, S.R., and Cooksey, L.M. 1993. Experimental infection of the eastern chipmunk (Tamias striatus) with the Lyme disease spirochete (Borrelia burgdorferi). J. Wildl. Dis. 29: 527-532.

Miyamoto, K., Nakao, M., Fujita, H., and Sato, F. 1993. The Ixodid ticks on migratory birds in Japan and the isolation of Lyme disease spirochetes from bird feeding ticks. Jpn. J. Sanit. Zool. 44: 315-326.

Moskoff, W. 1995. Veery (Catharus fuscescens). In The birds of North America. No. 142. Edited by A. Poole and F. Gill. The Academy of Natural Sciences, Philadelphia, and The American Ornithologists' Union, Washington, D.C. pp. 7-10.

Oliver, J.H., Cummings, G.A., and Joiner, M.S. 1993. Immature Ixodes scapularis (Acari: Ixodidae) parasitizing lizards from the southeastern U.S.A. J. Parasitol. 79: 684-689.

Olsén, B., Jaenson, T.G.T., and Bergström, S. 1995. Prevalence of
Borrelia burgdorferi sensu lato-infected ticks on migrating birds. Appl. Environ. Microbiol. 61: 3082-3087.

Ostfeld, R.S. 1997. The ecology of Lyme disease risk. Am. Sci. 85: 338-346.

Ostfeld, R.S., and Keesing, F. 2000. Biodiversity and disease risk: the case of Lyme disease. Conserv. Biol. 14: 722-729.

Ostfeld, R.S., and Lewis, D.N. 1999. Experimental studies of interactions between blacklegged ticks and wild turkeys. J. Vector Ecol. 24: 182-186.

Ostfeld, R.S., Jones, C.G., and Wolff, J.O. 1996. Of mice and mast: ecological connections in eastern deciduous forests. Bioscience, 46: 323-330.

Ostfeld, R.S., Keesing, F., Jones, C.G., Lovett, G.M., and Canham, C.D. 1998. Integrative ecology and the dynamics of species in oak forests. Integr. Biol. 1: 178-186.

Piesman, J., and Spielman, A. 1979. Host-associations and seasonal abundances of immature Ixodes dammini in southeastern Massachusetts. Ann. Entomol. Soc. Am. 72: 829-832.

Rand, P.W., Lacombe, E.H., Smith, R.P., Jr., Kilpatrick, C.W., Dragoni, C.A., and Caporale, D. 1993. Competence of Peromyscus maniculatus (Rodentia: Cricetidae) as a reservoir host for Borrelia burgdorferi (Spirochaetares: Spirochaetaceae) in the wild. J. Med. Entomol. 30: 614-618.

Rand, P.W., Lacombe, E.H., Smith, R.P., Jr., and Ficker, J. 1998. Participation of birds in the emergence of Lyme disease in southern Maine. J. Med. Entomol. 35: 270-276.

Richter, D., Spielman, A., Komar, N., and Matuschka, F.-R. 2000. Competence of American robins as reservoir hosts for Lyme disease spirochetes. Emerg. Infect. Dis. 6: 133-138.

Roth, R.R., Johnson, M.S., and Underwood, T.J. 1996. Wood thrush (Hylocichla mustelina). In The birds of North America. No. 246. Edited by A. Poole and F. Gill. The Academy of Natural Sciences, Philadelphia, and The American Ornithologists' Union, Washington, D.C. pp. 9-15.

Schmidt, K.A., and Ostfeld, R.S. 2000. Biodiversity and the dilution effect in disease ecology. Ecology. In press.

Schmidt, K.A., and Whelan, C.J. 1999. The relative impacts of nest predation and brood parasitism on seasonal fecundity in songbirds. Conserv. Biol. 14: 46-57.

Schmidt, K.A., Ostfeld, R.S., and Schauber, E.M. 1999. Infestation of Peromyscus leucopus and Tamias striatus by the blacklegged tick, Ixodes scapularis (Acari: Ixodidae), in relation to the abundance of hosts and parasites. J. Med. Entomol. 36: 749-757.

Schmidt, K.A., Goheen, J.R., Naumann, R., Ostfeld, R.S., Schauber, E.M., and Berkowitz, A.R. 2001, Experimental removal of strong and weak predators: mice and chipmunks preying on songbird nests. Ecology. In press.

Slajchert, T., Kitron, U.D., Jones, C.J., and Mannelli, A. 1997. Role of the eastern chipmunk (Tamias striatus) in the epizootiology of Lyme borreliosis in northwestern Illinois, U.S.A. J. Wildl. Dis. 33: 40-46.

Stafford, K.C., III, Bladen, V.C., and Magnarelli, L.A. 1995. Ticks (Acari: Ixodidae) infesting wild birds (Aves) and white footed mice in Lyme, CT. J. Med. Entomol. 32: 453-466.

Trine, C.L. 1998. Wood thrush population sinks and implications for the scale of regional conservation strategies. Conserv. Biol. 12: $576-585$.

Wolff, J.O. 1996. Population fluctuations of mast-eating rodents are correlated with production of acorns. J. Mammal. 77: 850856. 


\section{Appendix}

Table A1. Published reservoir competence values for each host species.

\begin{tabular}{|c|c|c|c|c|c|}
\hline \multicolumn{6}{|l|}{ Host species } \\
\hline Common name & Scientific name & $\begin{array}{l}\text { No. } \\
\text { examined }^{a}\end{array}$ & $\begin{array}{l}\text { Reservoir } \\
\text { competence }(C)\end{array}$ & Location & Source \\
\hline \multicolumn{6}{|l|}{ Rodents } \\
\hline \multirow[t]{3}{*}{ Eastern chipmunk } & Tamias striatus & 12 & 0.200 & Ipswich, Mass. & Mather 1993 \\
\hline & & 209 & 0.198 & Ipswich, Mass. & Mather et al. $1989 a$ \\
\hline & & 37 & 0.687 & Millbrook, N.Y. & \\
\hline Weighted average & & & 0.268 & & \\
\hline \multirow[t]{11}{*}{ White-footed mouse } & Peromyscus leucopus & 181 & 0.250 & East Haddam, Conn. & Anderson and Magnarelli 1984 \\
\hline & & 72 & 0.400 & Armonk, N.Y. & Fish and Daniels 1990 \\
\hline & & 339 & 0.463 & Ipswich, Mass. & Mather et al. $1989 a$ \\
\hline & & 20 & 0.460 & Ipswich, Mass. & Mather 1993 \\
\hline & & 31 & 0.810 & Ipswich, Mass. & Mather 1993 \\
\hline & & 36 & 0.760 & Naushon Island, Mass. & Mather 1993 \\
\hline & & 16 & 0.770 & Prudence Island, R.I. & Mather 1993 \\
\hline & & 426 & 0.875 & Naushon Island, Mass. & Mather et al. $1989 b$ \\
\hline & & 18 & 0.833 & Naushon Island, Mass. & Mather et al. $1989 b$ \\
\hline & & 82 & 0.350 & Wells Reserve, Maine & Rand et al. 1993 \\
\hline & & 163 & 0.935 & Millbrook, N.Y. & \\
\hline Weighted average & & & 0.631 & & \\
\hline \multicolumn{6}{|l|}{ Birds } \\
\hline \multirow[t]{4}{*}{ American robin } & Turdus migratorius & 4 & 0.250 & East Haddam, Conn. & Anderson and Magnarelli 1984 \\
\hline & & 22 & 0.000 & Lyme, Conn. & Magnarelli et al. 1992 \\
\hline & & 36 & 0.166 & Maine & Rand et al. 1998 \\
\hline & & 8 & 0.875 & East Haddam, Conn. & Anderson et al. 1990 \\
\hline Weighted average & & & 0.200 & & \\
\hline \multirow[t]{4}{*}{ Ovenbird } & Seiurus aurocapillus & 2 & 0.000 & East Haddam, Conn. & Anderson et al. 1986 \\
\hline & & 2 & 0.000 & East Haddam, Conn. & Anderson et al. 1990 \\
\hline & & 442 & 0.011 & Lyme, Conn. & Magnarelli et al. 1992 \\
\hline & & 2 & 0.000 & Maine & Rand et al. 1998 \\
\hline Weighted average & & & 0.011 & & \\
\hline \multirow[t]{3}{*}{ Veery } & Catharus fuscescens & 6 & 0.667 & East Haddam, Conn. & Anderson et al. 1986 \\
\hline & & 140 & 0.214 & Lyme, Conn. & Magnarelli et al. 1992 \\
\hline & & 54 & 0.426 & Maine & Rand et al. 1998 \\
\hline Weighted average & & & 0.285 & & \\
\hline \multirow[t]{2}{*}{ Wood thrush } & Hylocichla mustelina & 1 & 0.000 & East Haddam, Conn. & Anderson et al. 1986 \\
\hline & & 399 & 0.003 & Lyme, Conn. & Magnarelli et al. 1992 \\
\hline Weighted average & & & 0.003 & & \\
\hline
\end{tabular}


Table A2. Published values for larval and nymphal burdens on each host species.

\begin{tabular}{|c|c|c|c|c|c|c|c|}
\hline \multicolumn{2}{|l|}{ Host species } & \multirow[b]{2}{*}{$\begin{array}{l}\text { No. of } \\
\text { hosts } \\
\text { examined }\end{array}$} & \multirow[b]{2}{*}{$\begin{array}{l}\text { No. of } \\
\text { larvae/ } \\
\text { individual }\left(B_{1}\right)\end{array}$} & \multirow[b]{2}{*}{$\begin{array}{l}\text { No. of } \\
\text { nymphs/ } \\
\text { individual }\left(B_{\mathrm{n}}\right)\end{array}$} & \multirow[b]{2}{*}{ Location } & \multirow[b]{2}{*}{ Sampling dates } & \multirow[b]{2}{*}{ Source } \\
\hline Common name & Scientific name & & & & & & \\
\hline \multicolumn{8}{|l|}{ Rodents } \\
\hline \multirow[t]{4}{*}{ Eastern chipmunk } & Tamias striatus & 6 & 0.33 & 1 & Southeastern Mass. & $1975-1978$ & $\begin{array}{l}\text { Piesman and Spielman } \\
1979\end{array}$ \\
\hline & & 27 & 3.4 & & Great Island, Mass. & May-Sept. 1981-1983 & Mather et al. $1989 a$ \\
\hline & & 1 & 3 & & Crane's Beach, Mass. & May-Sept. 1981-1983 & Mather et al. $1989 a$ \\
\hline & & 144 & 4.19 & 4.90 & Millbrook, N.Y. & June-July 1998 & \\
\hline Weighted average & & & 3.93 & 4.00 & & & \\
\hline \multirow[t]{14}{*}{ White-footed mouse } & Peromyscus leucopus & 122 & 2.10 & 0.80 & East Haddam, Conn. & May-Sept. 1983 & $\begin{array}{l}\text { Anderson and Magnarelli } \\
1984\end{array}$ \\
\hline & & 620 & 10.75 & 2.23 & Cape Cod, Mass. & April-Sept. 1981-1984 & Davidar et al. 1989 \\
\hline & & 34 & 8.00 & & Armonk, N.Y. & August-Sept. 1986 & Fish and Daniels 1990 \\
\hline & & 200 & 2.38 & 0.80 & Lyme and East Haddam, Conn. & May-Sept. 1980 & Magnarelli et al. 1984 \\
\hline & & 135 & 1.52 & 0.48 & Lyme and East Haddam, Conn. & May-Sept. 1980 & Magnarelli et al. 1984 \\
\hline & & 106 & 2.06 & 0.24 & Lyme and East Haddam, Conn. & May-Sept. 1980 & Magnarelli et al. 1984 \\
\hline & & 453 & 14.50 & & Great Island, Mass. & May-Sept. 1981-1983 & Mather et al. $1989 a$ \\
\hline & & 649 & 18.00 & & Crane's Beach, Mass. & May-Sept. 1981-1983 & Mather et al. $1989 a$ \\
\hline & & 322 & 16.70 & & Naushon Island, Mass. & May-Sept. 1981-1983 & Mather et al. $1989 a$ \\
\hline & & 22 & 37.25 & 0.70 & Naushon Island, Mass. & $\begin{array}{l}\text { Aug.-Sept. 1987, } \\
\text { May } 1988\end{array}$ & Mather et al. $1989 b$ \\
\hline & & 12 & 7.30 & 10.10 & Naushon Island, Mass. & $\begin{array}{l}\text { Aug.-Sept. } 1987 \text {, } \\
\text { May } 1988\end{array}$ & Mather et al. $1989 b$ \\
\hline & & 1151 & 3.21 & 0.80 & Southeastern Mass. & $1975-1978$ & $\begin{array}{l}\text { Piesman and Spielman } \\
1979\end{array}$ \\
\hline & & 40 & 3.20 & 0.85 & Wells Reserve, Maine & July-Sept. & Rand et al. 1993 \\
\hline & & 414 & 9.65 & 0.68 & Millbrook, N.Y. & June-July 1998 & \\
\hline Weighted average & & & 9.45 & 0.72 & & & \\
\hline \multicolumn{8}{|l|}{ Birds } \\
\hline \multirow[t]{7}{*}{ American robin } & Turdus migratorius & 11 & 1.10 & 4.20 & East Haddam, Conn. & May-Sept. 1983 & $\begin{array}{l}\text { Anderson and Magnarelli } \\
1984\end{array}$ \\
\hline & & 59 & 2.60 & 2.00 & Armonk, N.Y. & May-August 1989 & Battaly and Fish 1993 \\
\hline & & 19 & 0.11 & 2.00 & Armonk, N.Y. & May 1984-May1985 & Battaly et al. 1987 \\
\hline & & 25 & 0.88 & 3.30 & Lyme, Conn. & May-Sept. 1990-1991 & Magnarelli et al. 1992 \\
\hline & & 120 & 1.08 & 0.91 & Maine & May-August 1989-1996 & Rand et al. 1998 \\
\hline & & 69 & 0.70 & 1.23 & Lyme, Conn. & May-Oct. 1989-1991 & Stafford et al. 1995 \\
\hline & & 6 & 1.00 & 9.67 & Millbrook, N.Y. & June-July 1998 & \\
\hline Weighted average & & & 1.21 & 1.74 & & & \\
\hline
\end{tabular}




\begin{tabular}{|c|c|c|c|c|c|c|c|}
\hline \multirow[t]{6}{*}{ Ovenbird } & Seiurus aurocapillus & 2 & 1.50 & 0.50 & East Haddam, Conn. & July-August 1984 & Anderson et al. 1986 \\
\hline & & 4 & 0.75 & 0.00 & Armonk, N.Y. & May 1984-May1985 & Battaly et al. 1987 \\
\hline & & 85 & 5.20 & 0.17 & Lyme, Conn. & May-Sept. 1990-1991 & Magnarelli et al. 1992 \\
\hline & & 19 & 0.32 & 0.05 & Maine & May-August 1989-1996 & Rand et al. 1998 \\
\hline & & 284 & 3.35 & 0.09 & Lyme, Conn. & May-Oct. 1989-1991 & Stafford et al. 1995 \\
\hline & & 12 & 0.18 & 1.78 & Millbrook, N.Y. & June-July 1998 & \\
\hline Weighted average & & & 3.46 & 0.15 & & & \\
\hline \multirow[t]{6}{*}{ Veery } & Catharus fuscescens & 2 & 3.00 & 1.50 & East Haddam, Conn. & July-August 1984 & Anderson et al. 1986 \\
\hline & & 1 & 0.00 & 0.00 & Armonk, N.Y. & May 1984-May1985 & Battaly et al. 1987 \\
\hline & & 78 & 1.80 & 0.80 & Lyme, Conn. & May-Sept. 1990-1991 & Magnarelli et al. 1992 \\
\hline & & 94 & 1.68 & 5.35 & Maine & May-August 1989-1996 & Rand et al. 1998 \\
\hline & & 245 & 1.06 & 0.38 & Lyme, Conn. & May-Oct. 1989-1991 & Stafford et al. 1995 \\
\hline & & 31 & 0.18 & 1.78 & Millbrook, N.Y. & June-July 1998 & \\
\hline Weighted average & & & 1.26 & 1.59 & & & \\
\hline \multirow[t]{6}{*}{ Wood thrush } & Hylocichla mustelina & 1 & 0.00 & 2.00 & East Haddam, Conn. & July-August 1984 & Anderson et al. 1986 \\
\hline & & 3 & 1.00 & 1.00 & Armonk, N.Y. & May-August 1989 & Battaly and Fish 1993 \\
\hline & & 13 & 0.31 & 0.23 & Armonk, N.Y. & May 1984-May1985 & Battaly et al. 1987 \\
\hline & & 191 & 2.09 & 0.39 & Lyme, Conn. & May-Sept. 1990-1991 & Magnarelli et al. 1992 \\
\hline & & 865 & 0.84 & 0.11 & Lyme, Conn. & May-Oct. 1989-1991 & Stafford et al. 1995 \\
\hline & & 17 & 0.18 & 1.78 & Millbrook, N.Y. & June-July 1998 & \\
\hline Weighted average & & & 1.04 & 0.19 & & & \\
\hline
\end{tabular}

